\title{
MAP SHOWING WATER WELLS AND SPRINGS IN THE TUNGSTEN QUADRANGLE, BOULDER, GILPIN, AND JEFFERSON COUNTIES, COLORADO
}

By

Dolores J. Gable

FOLIO OF THE

TUNGSTEN QUADRANGLE, COLORADO

MAP I-792-C

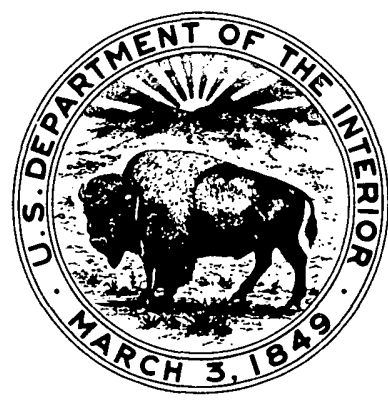

